http://dergipark.gov.tr/ataunizfd

\title{
Kırsal Mirasın Korunması: Beypazarı (Ankara) Hırkatepe Örneği
}

\author{
Canan KOÇ*1iD Ahmet KOÇ2 ${ }^{2}$ \\ ${ }^{1}$ Dicle Üniversitesi, Mimarlık Fakültesi, Mimarlık Bölümü, Diyarbakır, Türkiye \\ ${ }^{2}$ Iğdır Üniversitesi, Ziraat Fakültesi, Peyzaj Mimarlığı Bölümü, Iğdır, Türkiye \\ (*Sorumlu yazar e-mail: canan.koca@dicle.edu.tr) \\ DOI: 10.17097/ataunizfd.540932
}

Geliş Tarihi (Received Date): 16.03.2019

Kabul Tarihi (Accepted Date): 08.09.2019

\begin{abstract}
ÖZ: Kırdan kente olan göçle birlikte, kırsal alanlar giderek nüfus kaybetmekte ve kırsal miras tahrip olmaktadır. Kırsal yerleşmeler topoğrafya, iklim, jeoloji, hidroloji ve toprak özelliklerine göre şekillenmektedir. Kırsal mirasın yapı taşlarından olan geleneksel konutlar yapım teknikleri ve kullanılan malzeme açısından bölgenin özgün özelliklerini yansıtmaktadır. Bu bağlamda çalışmada, Ankara ilinde yer alan Beypazarı ilçesinin bir mahallesi olan höyük, tarihi kalıntılar, geleneksel kırsal mimari örnekleri ve Gündüzalp türbesini barındıran Hırkatepe köyü incelenmiştir. Yok olmaya başlayan kırsal mimarinin önemi vurgulanarak, korunmasına yönelik öneriler geliştirilmiştir.
\end{abstract}

Anahtar kelimeler: Kırsal miras, Koruma, Hırkatepe, Geleneksel mimari, Ankara/Beypazarı

Conservation of Rural Heritage: Case of Hırkatepe in Beypazarı (Ankara)

\begin{abstract}
Due to the migration from rural to urban areas, rural areas are losing their population and rural heritage is being destroyed. Rural settlements are shaped according to topography, climate, geology, hydrology and soil characteristics. Traditional dwellings which are the building blocks of rural heritage, reflect the features of the region in terms of construction techniques and materials. In this context, Hirkatepe which is the neighbourhood of Beypazar1 in Ankara, has the mound, the historical remains, traditional rural architecture and Gündüzalp tomb, were investigated in this study. Suggestions for conservation of the rural architecture that started to disappear, have been developed and laid emphasis on conservation.
\end{abstract}

Keywords: Rural heritage, Conservation, Hırkatepe, Traditional architecture, Ankara/Beypazarı

\section{GİRIS}

Kentlerin çekiciliği ve kırın iticiliği karşısında kırsal yerleşmelerin nüfusu giderek azalmakta, terk edilen bölgelerde kırın özgün dokusu giderek bozulmakta, kırsal mimari tahrip olmaktadır. Daha çok kentsel yerleşmelerin gelişme yönünde bulunan bazı kırsal yerleşmeler ise giderek kentle bütünleşmekte ve zaman içinde kentsel nitelik kazanmaktadır. Binlerce yıllık birikimin sonucu ortaya çıkan, doğal çevreye sıkı sıkıya bağlı ve onun izlerini taşıyan kırsal mimari, gelişen sosyo-kültürel ve ekonomik koşullar karşısında değişime uğramaktadır (Ceylan, 2012). Günümüzde, küreselleşmenin de etkisiyle kentler birbirine benzemekte, kimliksiz bir yapıya dönüşmekte, giderek kırsal yerleşmelere olan özlem doğmakta ve bu bölgelerin özgün dokusunun korunmas1 gerekliliğini ortaya çıkarmaktadır. "Mekânsal aynılaşmanın Türkiye'deki başlangıcı, 1950'lerde yaşanan modernleşme sürecine dayanmaktadır. Bu süreçte başlayan ve yaygınlaşan betonarme kullanımı, birçok yerleşimde yerel yapı malzemesi ve geleneksel yapım yöntemlerinin yerini almış ve apartman bloklarına geçiş hızla gerçekleşmiştir" (Şenol ve Er Akan, 2011). Zamanla, kırsal yerleşmelerde de yerel malzeme kullanımı terk edilerek betonarme yapılar yaygınlaşmaya başlamıştır.

Kırsal mirasın korunması yönündeki çalışmaların başlangıcı 1964 tarihli Venedik
Tüzüğü’ne dayanmaktadır. Buna göre, korunması gerekli kültür varlıkları arasında tarihi bir olaya tanıklık eden kentsel ya da kırsal yerleşmeler de sayılmaktadır (Ahunbay 2004; Levi ve Taşçı, 2017). Sonraki y1llarda düzenlenen 1975 tarihli Avrupa Mimari Tüzüğü ve Küçük Tarihi Kentlerin Korunması Sempozyumu sonuç bildirgesi (Özcan, 2017), 1977 yılında Granada'da yapılan "Bölgesel Planlama İçinde Kırsal Mimari” Sempozyumu (Levi ve Taşçı, 2017) ve 1989 yılında hazırlanan "Kırsal Mimari Mirasın Korunması ve Değerinin Artırılması Hakkında Tavsiye Kararı'nda kırsal mirasın korunması gerekliliğinin önemi vurgulanmıştır. 2001 yılında ICOMOS üyesi ülkelerde tarihi köylerin korunmasına yönelik etkinlikler düzenlenmiş (Levi ve Taşçı, 2017), Avrupa Parlamentosu'nun 2006 yılında aldığ “Avrupa'nın Kırsal ve Ada Bölgelerindeki Doğal, Mimari ve Kültürel Mirasın Korunması Kararları" ile Avrupa'daki kırsal alandaki kültürel mirasa vurgu yapılmıștır (Eres, 2008).

"Başta Avrupa olmak üzere dünyada kırsal kültür mirasının kapsamını tanımlayan, koruma sorunlarını ortaya koyarak çözüm önerileri getiren kararlarla, toplumların özgün kimlikleri ile somut ve soyut tüm kültür mirası bir bütün olarak korumayı hedeflemektedir. Her ne kadar Türkiye uluslararası sözleşmeleri kabul ederek koruma alanındaki yeni gelişmeleri izler bir görüntü oluşturmaktaysa da, bu 
yeni kavramların uygulamaya yansıma süreci oldukça yavaş ilerlemektedir" (Eres, 2008). Türkiye'de kırsal miras ile ilgili koruma çalışmaları daha çok Yörük Köyü (Safranbolu), Birgi (Ödemiş/İzmir), Şirince (Selçuk/İzmir), Cumalıkızık (Bursa) gibi turizmin aktif olduğu ve sit alanı ilan edilmiş yerleri kapsamaktadır.

Kırsal miras, zaman içinde kırsal bölgeyi oluşturan ve toplumsal ilişkileri yansıtan somut ve somut olmayan kültür varlıklarını kapsamaktadır (CEMAT, 2003). Cohen and Sofer (2017), kirsal mirasın iki mekânsal etkisinden bahsetmektedir. Birincisi, tarım ve yapılı çevre arasındaki ilişkidir. İkincisi ise, miras değerlerinin ulusal hafiza, ulusal olaylar ve biyografiler kadar her yerleşmenin yerel hafizası ile ilgili olduğudur. Rapoport (1969) da kırsal mimarinin biçimlenmesine etki eden esas faktörün kültür olduğunu vurgulamakta ve diğer etkenleri; iklim ihtiyaçları, malzeme, konstrüksiyon ve teknoloji, arazinin yapısı, savunma, ekonomi, din ve sosyo-kültürel etkenler şeklinde belirtmektedir (Çınar, 2014)

"Kırsal yerleşmeler, doğal çevrenin karakteri ile biçimlenmekte ve yerel karakter kazanmaktadır. Doğanın yapılaşmış çevrelerden daha baskın olduğu görülmektedir. Yerleşme alanları olarak dere kıyıları, yamaçları veya dağ etekleri seçilebilmektedir" (Eminağaoğlu ve Çevik, 2006). "Kırsal peyzajlar, yerel tarımsal ve kırsal üretim biçiminin, yerleşim dokusu ve yapı kültürüne yansıdığı mekânlardır. $\mathrm{Bu}$ tür mekânlarda genel kullanıma açı alan ve yapılar ile tarımsal üretim alanları ve konutlar ilginç, özgün ve yerel kimlik taşıyan dokular oluşturmaktadır" (Kiper, 2013). Topoğrafya, iklim, jeolojik ve toprak gibi peyzajın doğal elemanları ile toplumun sosyo-kültürel ve ekonomik özellikleri kırsal yerleşmelerin ve kırsal mimarinin şekillenmesinde etkili olmaktadır.

Kırsal mimari kültür ve geleneklerden etkilenen tasarım karalarıyla inşa edilmekte ve yeryüzündeki iklim, arazi ve kültür çeşitliliğine bağlı olarak farklılaşmaktadır (Zhai ve Previtali, 2010). Bölgenin topoğrafik özellikleri yerleşimin sınırlandırılmasını ve mimaride farklılaşmayı zorunlu kılmıştır. Kırsal mimarinin bulunduğu konuma bağlı olarak bitki örtüsünün kullanımı da malzeme ve görsel zenginlik açısından önem taşımaktadır. Örneğin, orman köylerinde bitki örtüsü görsel etki sunmakta ve yap1 malzemesi olarak da kullanılmaktadır. Ayrıca, "Kırsal yerleşimlerin oluşumunda topoğrafik özelliklerle ilişkili olarak yerleşim alanının jeolojik yapısı da etkili olmaktadır. Jeolojik yapı, o yöredeki yapılarda kullanılacak olan malzemeyi belirleyerek, yerel mimarinin oluşumuna katkı sağlamaktadır. Dağlık alanlarda genellikle taş malzeme hâkim iken, alüvyal sahalar veya ovalarda toprak malzeme daha fazladir" (Gözenç ve Gümüș,1998; Akgün, 2013).

İklimsel özelliklere bağlı olarak yapı malzemesi ve mekân kullanımı değişkenlik göstermiştir. "Ulaşım olanaklarının kısıtlı oluşu yapım tekniklerinin ve konut biçimlerinin farklılaşmasına neden olmuştur (Sözen ve Eruzun,1996). Bu nedenle ulaşımın zor olduğu yerleşmelerdeki yapılarda kullanılacak malzeme, çevredeki malzemeyle sınırlı kalmış ve bu durum kırsal yerel mimarinin oluşmasına katkı sağlamıştır" (Akgün, 2013).

Özetle, topoğrafya, rölyefler, vejetasyon, su, 1şık, klima etkileri ve doğal çevreyi kullanma, değiştirme, tamamlama, sembolize etme ve görselleştirmenin sonucu olarak özgün kırsal mimari sunumlarda biçim, malzeme, detay ve mekan organizasyonları ön plana çıkmaktadır (Çevik vd., 2003; Eminağaoğlu ve Çevik, 2006). Bu bağlamda, yerel ve doğal malzemenin kullanıldığı, doğa ile iç içe olan kırsal mimari sürdürülebilir gelişme içinde önemli bir paya sahiptir. Ancak, kentleşme baskısı içinde ya korunamamakta ya da terk edilmektedir. Bu bağlamda, çalışmada Ankara ili Beypazarı ilçesi Hırkatepe Köyü (Mahallesi) ele alınarak, yok olmaya başlayan kırsal mimarinin korunmasına yönelik önerilerde bulunulmaktadır.

\section{MATERYAL VE METOT}

Çalışma ile ilgili yerli ve yabancı literatür taraması yapılmış, kullanıcı ile görüşülmüş, yerinde gözlem ve fotoğraflama tekniği ile görseller oluşturulmuştur. Uydu görüntüleri üzerinden ulaşım haritaları çıkarılmıştır. Alana ait yükselti ve eğim analizinin hazırlanmasında Arcgis programından yararlanılmıştır.

Çalışma kapsamında Hırkatepe kırsal yerleşiminin doğal yapısı, sosyo-kültürel yapısı ve yerleşimde bulunan kırsal mimari özellikleri değerlendirilmiş, yerleşmedeki sorun ve potansiyelleri ortaya koymak amacıyla GZFT (Güçlü Yönler, Zayıf Yönler, Fırsatlar, Tehditler) analizi yapılmıştır. Ayrıca, kırsal mimariyi koruma gerekliliği vurgulanarak öneriler geliştirilmektedir.

Çalışma alanı olarak Ankara ili Beypazarı ilçesinin mahallelerinden biri olan Hırkatepe seçilmiştir. Hırkatepe, Beypazarı kent merkezinin kuzeybatisinda yer almakta olup, merkeze $16 \mathrm{~km}$ mesafededir (Şekil 1). $40^{\circ} 11^{\prime \prime} \mathrm{K}$ ve $31^{\circ} 45^{\prime} \mathrm{D}$ koordinatları arasında konumlanmaktadır. 
C. Koç, A. Koç

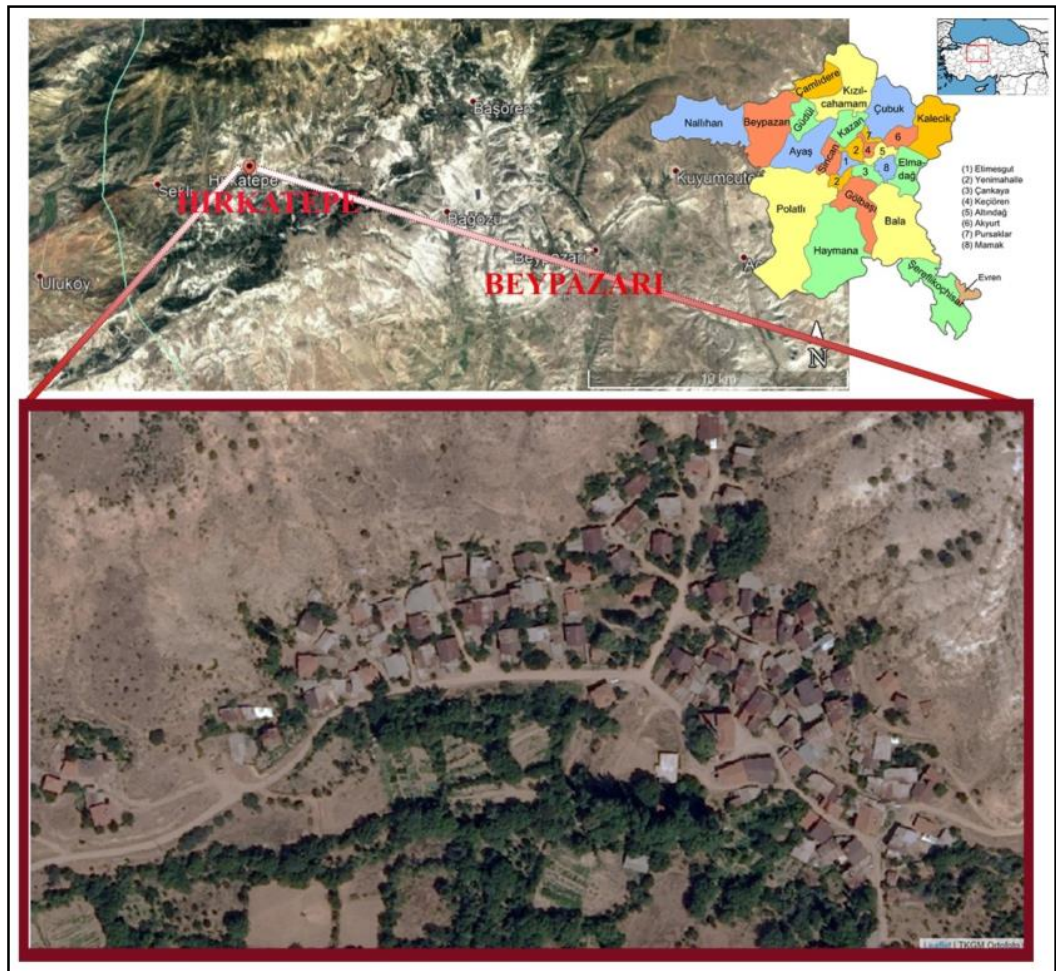

Şekil 1. Hırkatepe'nin konumu

\section{BULGULAR VE TARTISMA}

Çalışmanın bu bölümünde Hırkatepe'de kırsal mirası şekillendiren özellikler ele alınmaktadır. Bu bağlamda, Hırkatepe'nin fiziki mekân (doğal) özellikleri, toplumsal yapısı ve geleneksel mimariye ait yapım sistemleri ve malzemeler değerlendirilmektedir.
Hırkatepe'nin Fiziki Mekan (Doğal) Yapısı

Hırkatepe yerleşiminin güneyinden dere geçmekte ve yerleşimin olduğu bölgenin yüksekliği 830-885 m, eğimi ise \% 0-6 arasında değişmektedir (Şekil 2,3). Hırkatepe Köyü, Köroğlu Dağlarının uzantısı Aladağ ve Keltepe'nin güney eteklerinin paralelindeki derin vadidedir (Gündüzalp, 2003). Yerleşme, kuzeye doğru gelişme göstermiştir.

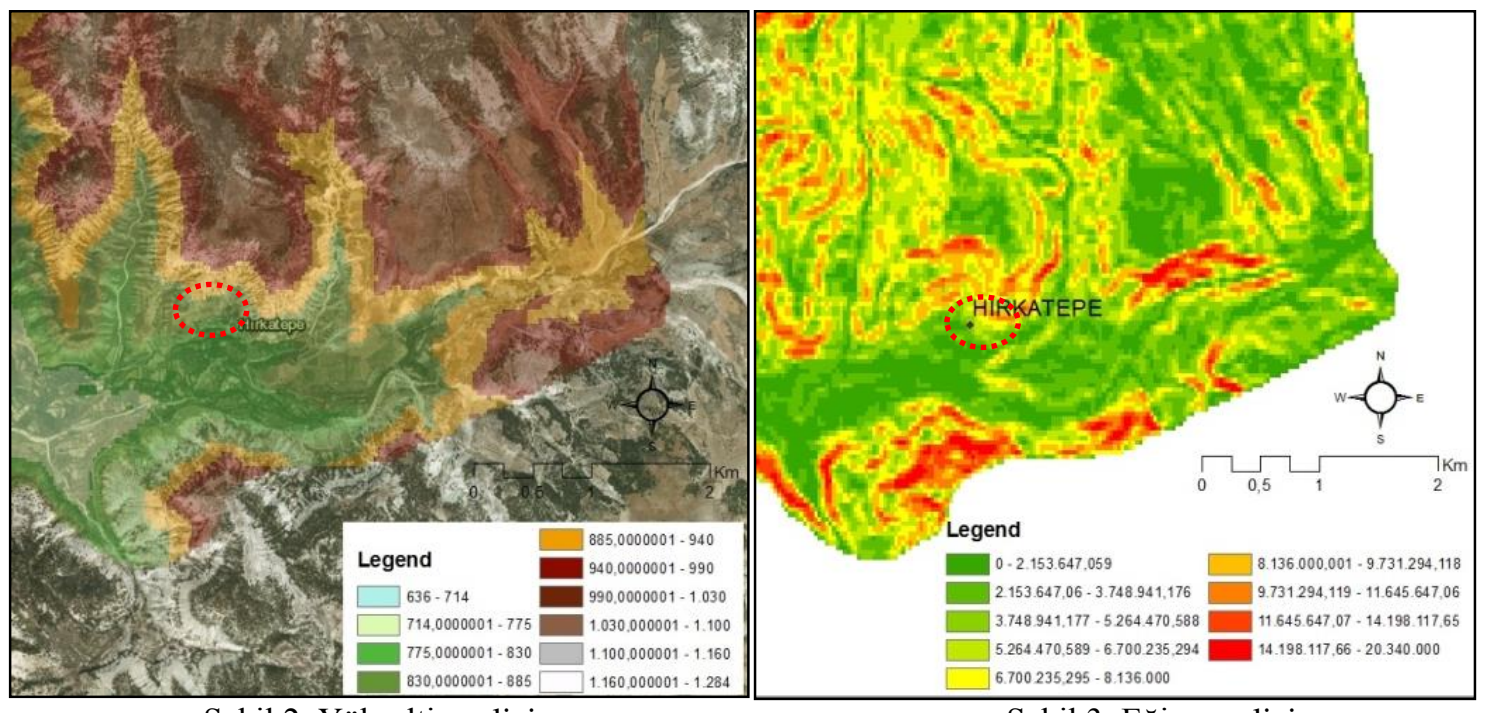

Şekil 2. Yükselti analizi

Şekil 3. Eğim analizi 
Yerleşmenin ana ulaşım aksını köyleri birbirine bağlayan doğu-batı aksındaki yol oluşturmaktadır. Organik sokak dokusu hâkim olup, sokaklar topoğrafyanın elverdiği ölçüde şekillenmiştir (Şekil 4). Doğu-batı aksındaki ana yol asfalt kaplı olup, genişliği 5-6 m kadardır (Şekil 5). Diğer yolların genişlikleri değişkenlik göstermekte ve parke taş kaplıdır (Şekil 6). Ayrıca, konutlar arasında, 1-1,5 m genişliğinde toprak yollar da bulunmaktadır (Şekil 7). Yerleşmeye ulaşım genellikle bireysel imkânlarla sağlanmaktadır. Haftanın belli günlerinde Beypazarı'na ulaşımı sağlayan toplu taşıma mevcuttur.

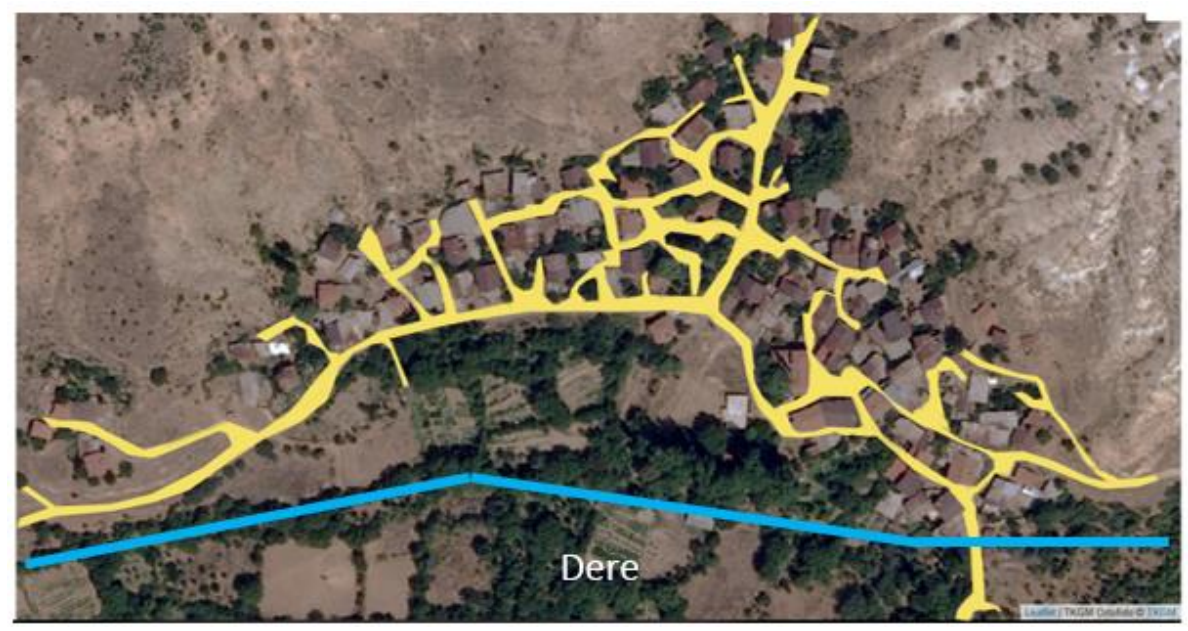

Şekil 4. Ulaşım ağ

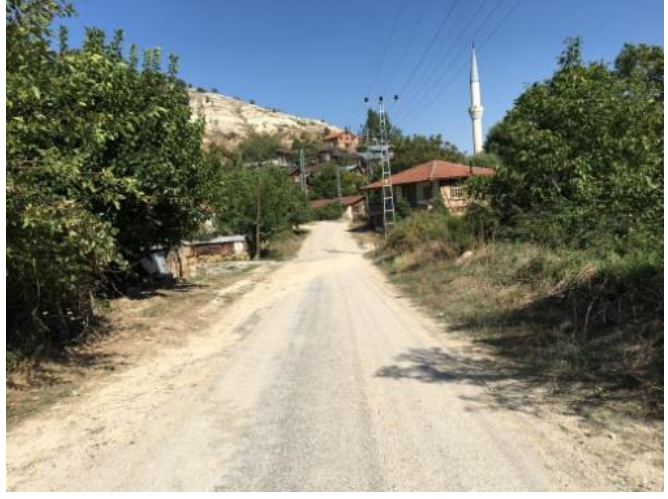

Şekil 5. Ana yol

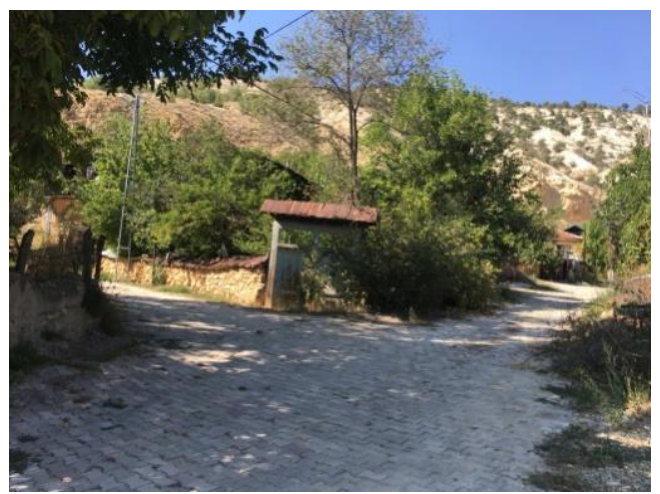

Şekil 6. Ara yollar

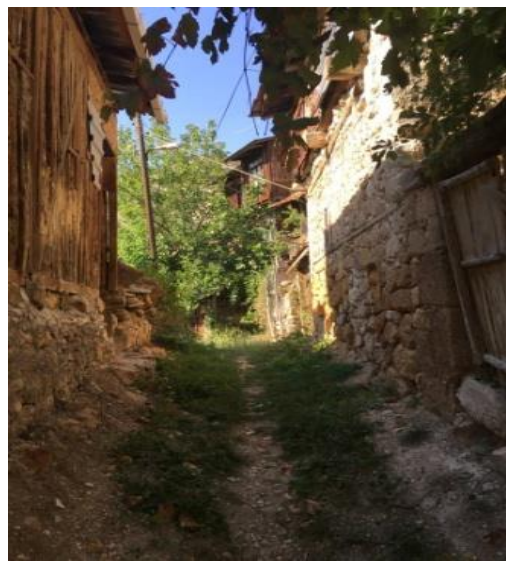

Şekil 7. Toprak yollar 
Yerleşmenin merkezini köy konağı, cami ve okulun bulunduğu bölge oluşturmaktadır (Şekil 8). Köy yerleşiminde ilkokul, cami, köy konağından oluşan kamusal nitelikli yapıların yanı sıra konutlar, ahırlar ve depolar bulunmaktadır (Şekil 9-10).
Yerleşimde nüfusun azlığı ve taşımalı eğitime geçilmesine bağlı olarak ilkokul aktif olarak kullanılmamaktadır. Sağlık hizmeti ise Beypazarı ilçe merkezinden ve Ankara İli’nden sağlanmaktadır.

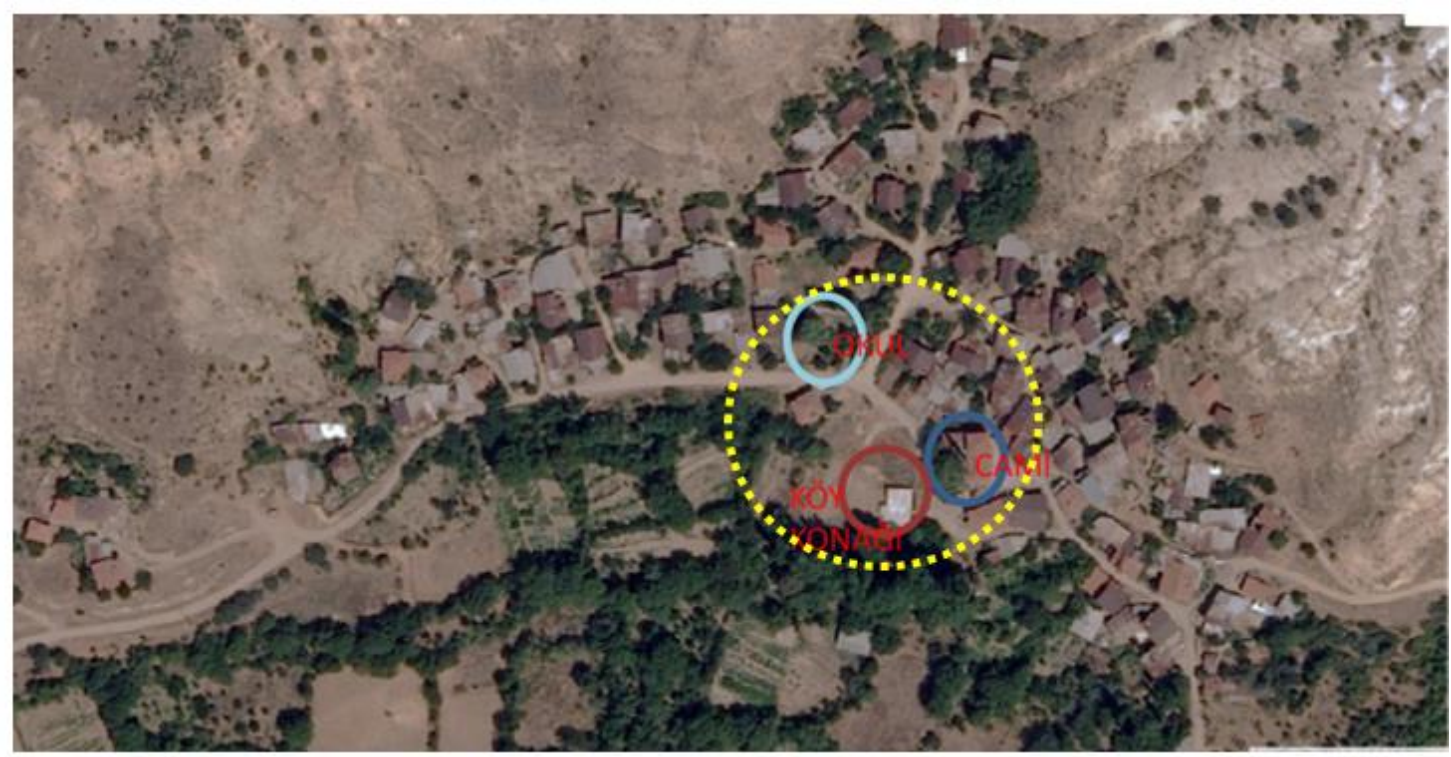

Şekil 8. Yerleşme merkezi

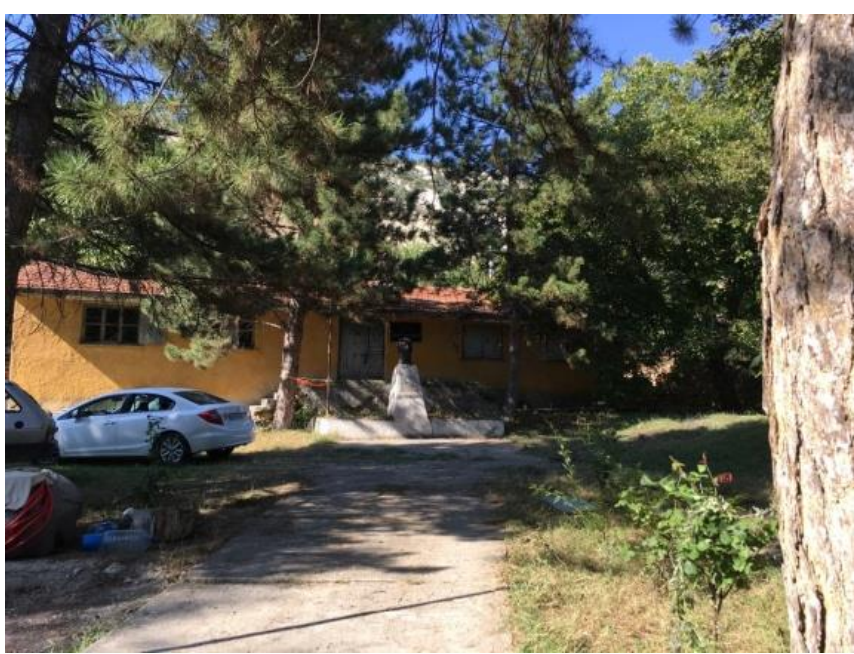

Şekil 9. İlkokul

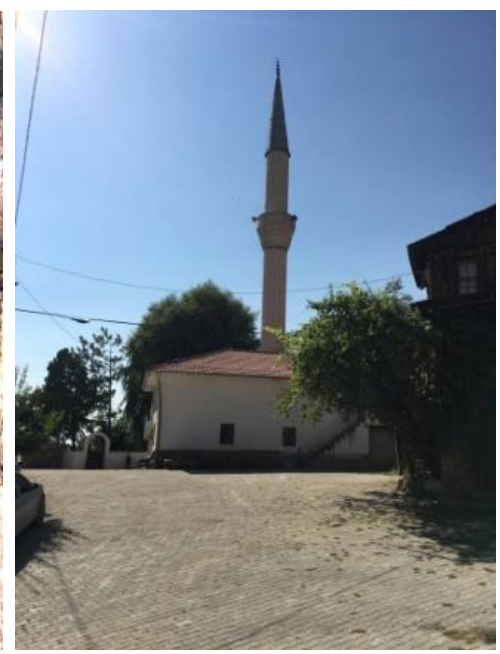

Şekil 10. Cami
Yerleșmenin güneyinde yer alan dere sulu tarıma imkân tanımıştır. Yerleşimde yaşayanların genel geçim kaynağını tarım ve hayvancılık oluşturmaktadır. Tarım ürünlerinden meyve ve sebze yetiştiriciliği halkın geçim kaynağına katkıda bulunurken, hayvancılık olarak küçük baş hayvan yetiştiriciliği katkıda bulunmaktadır.

\section{Yerleşimin Toplumsal Yapısı}

Yerleşme sınırları içinde höyüğün ve tarihi kalıntıların bulunması, köklü bir tarihi geçmişin olduğunu göstermektedir (Şekil 11). "Hırkatepe Höyük, Hırkatepe Köyünün girişinde Gündüzalp Türbesinin bulunduğu tepedir. Hirkatepe Köyünün eski adı Kırka / Hırka'dır. Höyüğün Tunç Çağı'nda iskân gördüğü belirtilmektedir. Günümüzde höyük üzerinde Osmanlı'nın kurucusu Osman Gazi'nin dedesi, Ertuğrul Gazi'nin babası ve Hayme Ana'nın eşi olan Gündüzalp'in türbesi bulunmaktadır" (Anonim, 2019). 


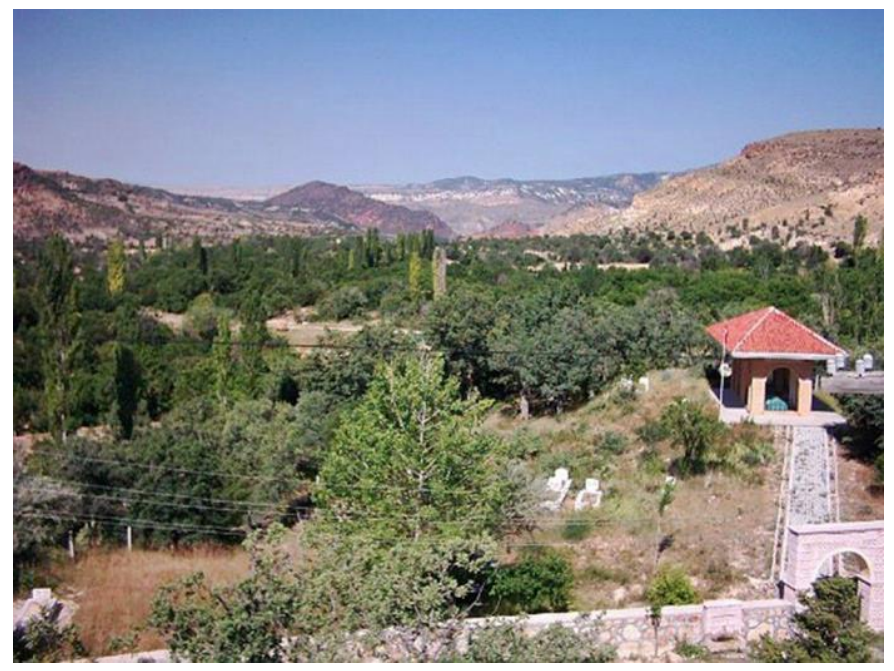

Şekil 11. Hırkatepe höyüğü (Anonim, 2019)

Hırkatepe Köyünün kuruluşu 1188 ile 1281 tarihlere arasına dayanmaktadır (Uzunçarşıll, 1988). Çoğu rivayete göre Türklerin Anadolu'ya göç etmeleri ve Osmanlı Devletinin kuruluşuna kadar gider. "Sultan Alparslan'ın Anadolu'yu fethi sonrasında, Selçuklu yönetimi zamanında da Türk boyları Anadolu'ya gelmeye devam etmişlerdir. Bunlardan birisi de Gazi Gündüzalp yönetimindeki Kayı boyudur. Önce Haymana civarına yerleşmişler, daha sonra kendilerine Selçuklu Sultanlığı tarafından yurt olarak verilen Söğüt Domaniç Çarşamba'ya geçmişlerdir. $\mathrm{Bu}$ göç sırasında Gazi Gündüzalp, kuvvetle muhtemel bir baskın esnasında çıkan muharebede şehit olmuş, mezarının bulunduğu yere kayı boyundan 40 kişi bırakılmış, mezara sahip olmaları ve orayı yurt tutmaları sağlanmıștır. Daha sonra Gazi Gündüzalp'in mezarını ziyarete gidenlerin ve gelenlerin Kırka gidelim, Kırka varalım, Kırka'dan geliyoruz demeleri dolayısıyla köyün adı Kırka olarak söylenegelmiş ve benimsenmiştir" (Gündüzalp, 2003). "Kırka olarak anılan köyün adı zamanla Hırka (tepe) olarak değişmiştir. Türbe üzeri bir çatıyla kaplanmış, namaz kılmak için bir bölümü olan açık bir türbedir"' (Şekil 12) (Anonim, 2019).
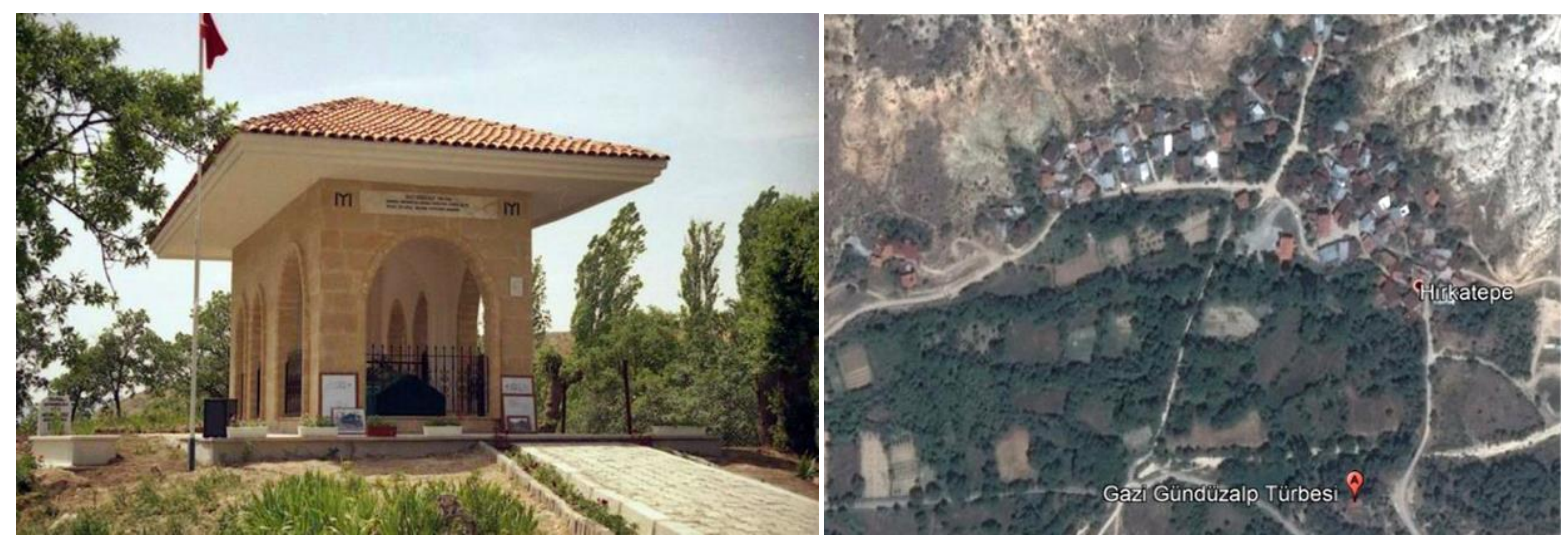

Şekil 12. Gazi Güngüzalp türbesi ve konumu (Anonim, 2019)

Yerleşmenin nüfusu 1935 y1lında 355 kişi iken, 1960 yılında 425 kişi ile en yüksek nüfusa sahip olmuştur (Çizelge 1 ve Şekil 13). Günümüzde ise nüfus 121 kişi olarak belirlenmiştir. Nüfus yaz aylarında artmakla birlikte, kış aylarında yerleşmede yaşayan hane sayısı oldukça azdır. 
Çizelge 1. Hırkatepe'nin nüfus değişimi (Yaman Kocadağlı, 2013; TUIK, 2019)

\begin{tabular}{|l|r|r|r|r|r|r|r|r|r|r|r|}
\hline Yillar & 1935 & 1940 & 1950 & 1960 & 1970 & 1980 & 1990 & 2000 & 2011 & 2015 & 2018 \\
\hline Nüfus & 355 & 349 & 357 & 425 & 366 & 316 & 305 & 214 & 84 & 80 & 121 \\
\hline
\end{tabular}

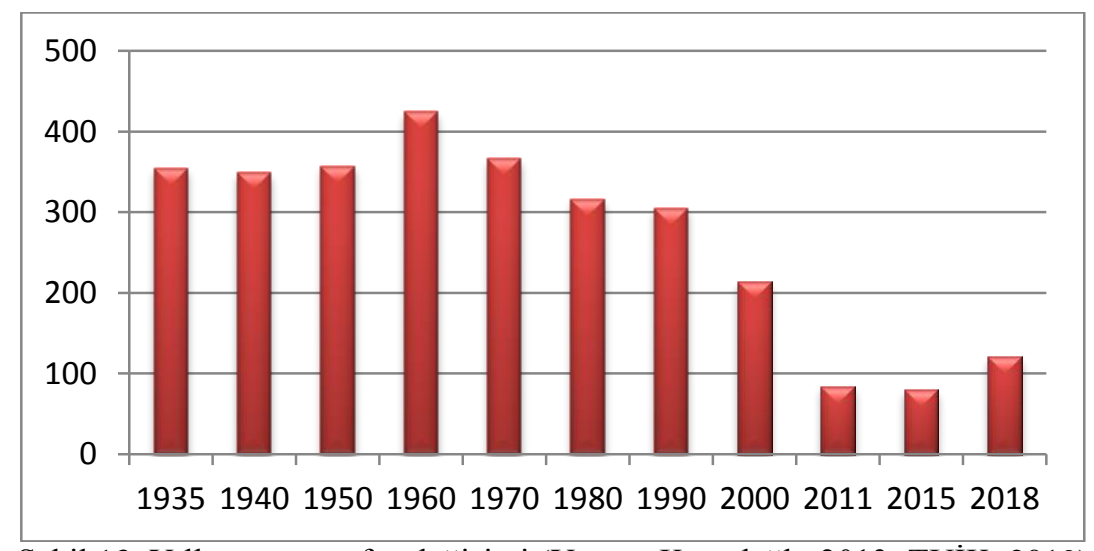

Şekil 13. Yıllara göre nüfus değişimi (Yaman Kocadağlı, 2013; TUiK, 2019)

Hırkatepe'deki imkânların sınırlı olması sebebiyle genç nesil köy dışında yaşamak istemekte, yaz ayları ve bayram ziyaretlerinin dışında bu yerleşmeye gelmemektedir. Bu durum geleneksel yaşam biçimlerinin dönüşmeye başladığını göstermektedir.

Yerleşimde Yapım Sistemleri ve Malzemeleri

Kırsal mimaride önemli olan işlevdir ve estetik kaygı ikinci planda gelmektedir (Çekül, 2012). "Bu nedenle kırsal yerleşimlere yakın çevreden elde edilen malzemelerle bölgenin iklimi ve topoğrafyasına uygun, ihtiyacı karşılayacak plan düzeninde konutlar inşa edilmektedir" (Avcı ve Atik, 2016). Hirkatepe'deki yapılar eğime paralel olarak yerleştirilmiş olup, konutlardaki ana mekânlar güney, güneydoğu ve güneybatı yönlerine bakmaktadır. Konutlar, bahçe içinde yer almaktadır ve bahçe duvarları genellikle taştır. Son dönemde bahçelerin sınırlandırılmasında tel, çit, tuğla gibi malzemeler kullanılmıştır. Konuta ulaşmak için bahçe kapısından geçmek gerekir. Orijinal bahçe kapısı iki kanatlı ve ahşap olup, sonradan yenilenen kapılarda malzeme değişikliğe uğramıştır. Bahçede genellikle kümes, kulübe vb. yapılaşmalar ile çeşme yer almaktadır.

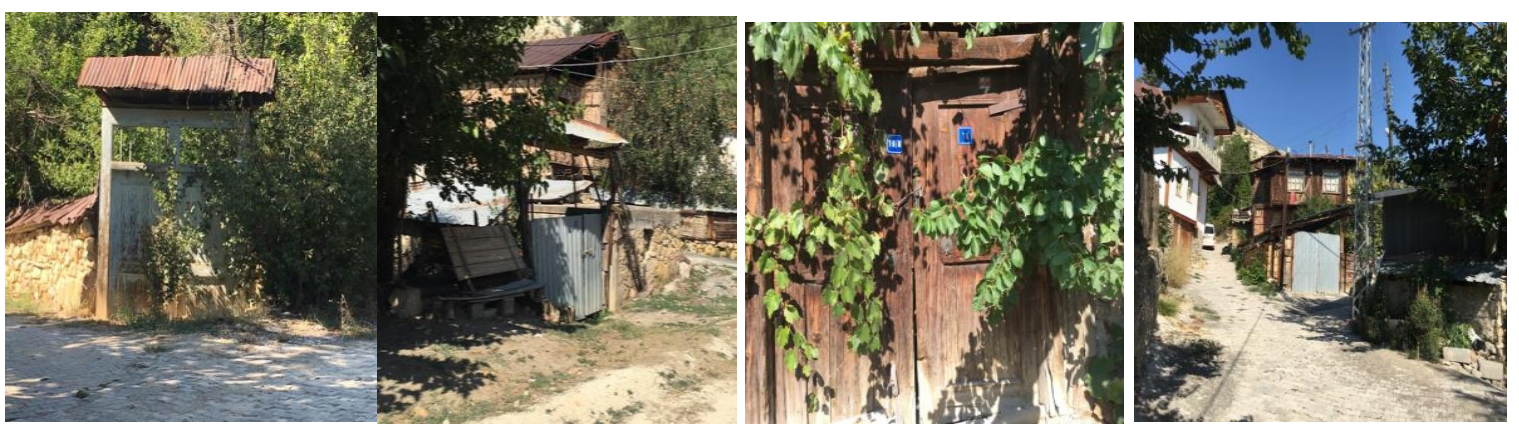

Şekil 14. Bahçe duvarı ve kapı örnekleri

Konutlar, çoğunlukla zemin +1 kat ya da zemin+2 kat adedine sahiptir (Şekil 15). Giriş cephesinde çatının bulunduğu katta bir oda bulunmaktadır. Bu odalar genellikle misafir ve aile içi diğer bireylerin konaklaması için oluşturulmuştur.
Konutların zemin katları geçmişte ahır olarak kullanılmış olup, konutların 1sıtılmasında bu olanaktan yararlanılmıştır. Günümüzdeki kullanımları ise daha çok depo ya da kiler şeklindedir. 


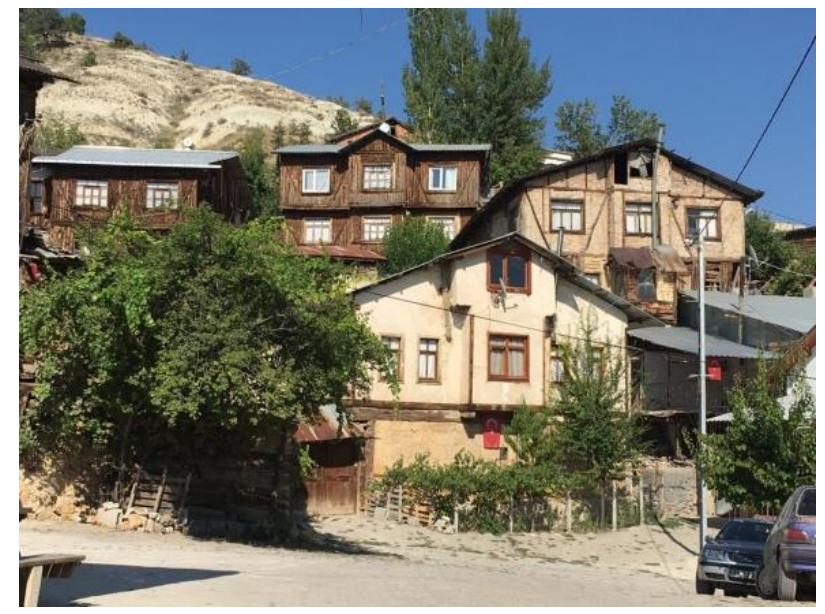

Şekil 15. Konutlarda kat adetlerine örnek

Geleneksel yapılarda kullanılan malzemeler bölgenin konumu ve iklimine bağlı olarak farklılaşmaktadır. "Kırsal yapılar genellikle yakın çevreden sağlanan yapı malzemeleriyle geleneksel sistemde ve yalın biçimlenişte inşa edilmektedir" (İner ve Erdoğan,2010). Hırkatepe'de kolaylıkla erișilebilir bir malzeme olan taş, kerpiç ve ahşap yaygın olarak

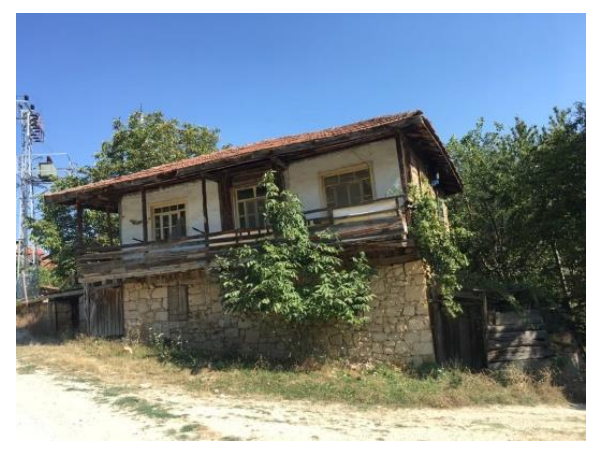

Şekil 16. Zemin kat taş ve üst kat kerpiç

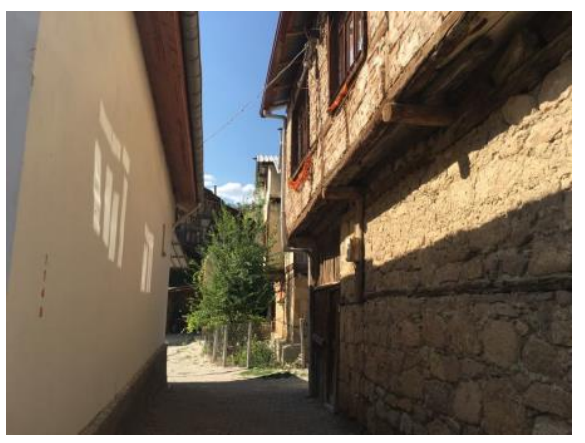

kullanılmıştır. Hırkatepe'deki geleneksel konutlarda malzeme kullanımı aşağıda belirtildiği gibi üç şekilde olmuştur:

- Zemin kat taş ve üst katlar kerpiç (Şekil 16)

- Zemin kat taş ve üst katlar ahşap (Şekil 17)

- Zemin kat taş ve üst katlar tuğla (Şekil 18)

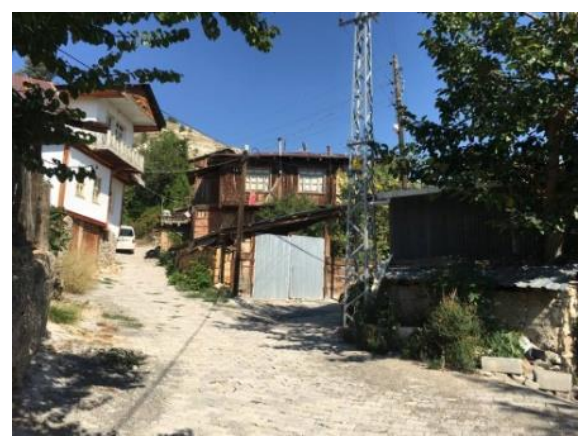

Şekil 17. Zemin kat taş ve üst katlar ahşap

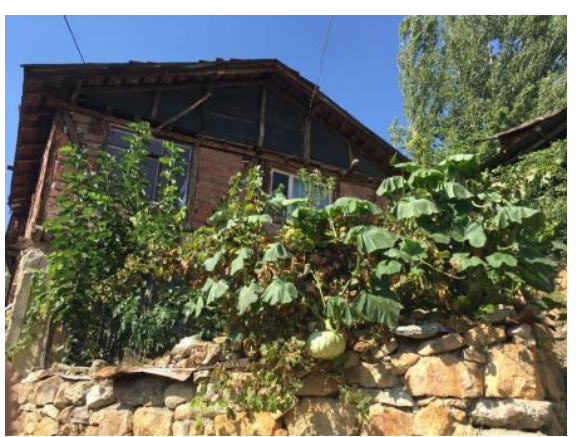

Şekil 18. Zemin kat taş ve üst katlar tuğla malzeme

Ülkemizde Çengel Köyü (Pınarbaş1/ Kastamonu), Çamlık Köyü (İkizdere/Rize), Maden Köyü (Şavşat/Artvin) gibi orman köylerinde ahşap yapılara sıklıkla rastlanmaktadır. Benzer şekilde, orman köyü olan Hırkatepe'de ahşap yaygın olarak kullanılmıştır. Konutlardaki döşemeler çoğunlukla 
ahşaptır. Sıva ve harç yapımında çamur, kireç ve saman kullanılmıştır. Zemin katlar yığma sistemle, üst katlar ahşap ve karkas sistemle inşa edilmiştir. Yerleşmenin nüfus kaybeden özelliğine bağlı olarak yeni yapılaşma yaygın değildir. Bağ evleri şeklinde ahşap ya da prefabrike konutlar inşa edilmektedir. Çalışma alanında en son yapılan köy konağı ise betonarmedir.

Yerleşmelerin özgün dokusunun korunması ve geleceğe aktarılması sürdürülebilirliğin sağlanması için önemli bir gerekliliktir. Mioara and Teodora (2015), kırsal mirası, sürdürülebilir ekonomik büyümeyi destekleyen en önemli öğelerden biri olduğunu belirtmektedir. Tarım ve yerel üretim ile turizm potansiyeline sahip kırsal mirası barındıran yerleşmeler ekonomik kaynak olarak görülmektedir. Literatürde kırsal mirasın korunmasını ele alan çalışmalarda Çin, Hindistan, İran, İngiltere, İsrail, İtalya ve Romanya gibi ülkeler öne çıkmakta ve korumayı turizmle birlikte değerlendirmektedir.

Kırsal miras, sosyo-kültürel özellikler, tarım ve turizm kaynaklı ekonomik gelirler ve geçmiş hakkında bilgi vermesi gibi nedenlerden ötürü korunmalıdır (CEMAT, 2003). Kirsal alanda mimari mirasın korunması, onu oluşturan belleğe, sosyal ve kültürel geleneklere sahip çıkılmasına doğrudan bağlıdır. (Muşkara, 2017). "Bunun için öncelikle kırsaldaki yaşamın korunması, sürekliliğinin sağlanması gerekir"(Kurtuluş ve Şahin Güçhan, 2015). Kırsal mimarinin korunması amacıyla yerleşmenin bütün olarak ele alınması gereklidir. Dolayısıyla çalışma alanına ilişkin GZFT (Güçlü Yönler, Zayıf Yönler, Fırsatlar ve Tehditler) Analizi yapılarak yerleşmenin özellikleri ortaya konmuştur (Çizelge 2).

\section{Çizelge 2. GZFT Analizi}

\begin{tabular}{|c|c|}
\hline 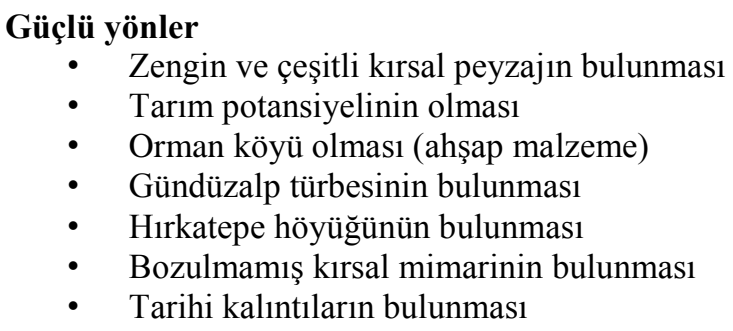 & $\begin{array}{l}\text { Zayıf yönler } \\
\text { • Çoğunlukla yaşlı nüfusun yaşaması } \\
\text { • Orta ve düşük gelir grubunun yaşaması } \\
\text { • İstihdam imkânlarının sınırlı olması } \\
\text { - Göç vermesi } \\
\text { • Yatırım yapılmaması } \\
\text { - Koruma konusunda bilincin olmaması }\end{array}$ \\
\hline $\begin{array}{l}\text { Firsatlar } \\
\text { - Beypazarı'na yakın konumda olması } \\
\text { - Toplumsal dokunun homojen olması } \\
\text { - Özgün kırsal mimarinin mevcut olması } \\
\text { - Yeni maden ocaklarının açılması } \\
\text { - Enerji üretim santralinin kurulması }\end{array}$ & $\begin{array}{l}\text { Tehditler } \\
\text { - Altyapı ve restorasyon çalışmaları için } \\
\text { bütçenin yetersiz olması } \\
\text { - Maden ocakları ve enerji üretim santralinin } \\
\text { çevre kirliliğine sebep olması } \\
\text { - } \quad \text { Kefine arayıcılarının olması } \\
\text { Kırsal mimarinin yok olma tehlikesi içinde } \\
\text { bulunması } \\
\text { Tarım ve hayvancılık gelirlerinin düşmesi }\end{array}$ \\
\hline
\end{tabular}

Yerleşmenin köklü tarihi geçmişi ve ekolojik özellikleri güçlü yönler olarak, göçün olması ve koruma konusundaki bilgi yetersizliği ise zayıf yönler olarak değerlendirilmiştir. Çalışma alanında eğitim, sağlık, ticaret, istihdam gibi olanakların kısıtlı olması genç nüfusun kente göçüyle sonuçlanmıştır. Konumu ve sahip olduğu değerler firsat oluştururken, ekonomik imkânsızlıklar ve kırsal mimarinin giderek yok olmaya başlaması önemli tehditler arasında sayılmaktadır. Daha çok yaşlı nüfusun barındığı geleneksel kırsal mimari yok olma tehdidi altındadır. Yapılarda tahribat başlamış olup, bazı bölümler kullanılamaz hale gelmiştir (Şekil 19).

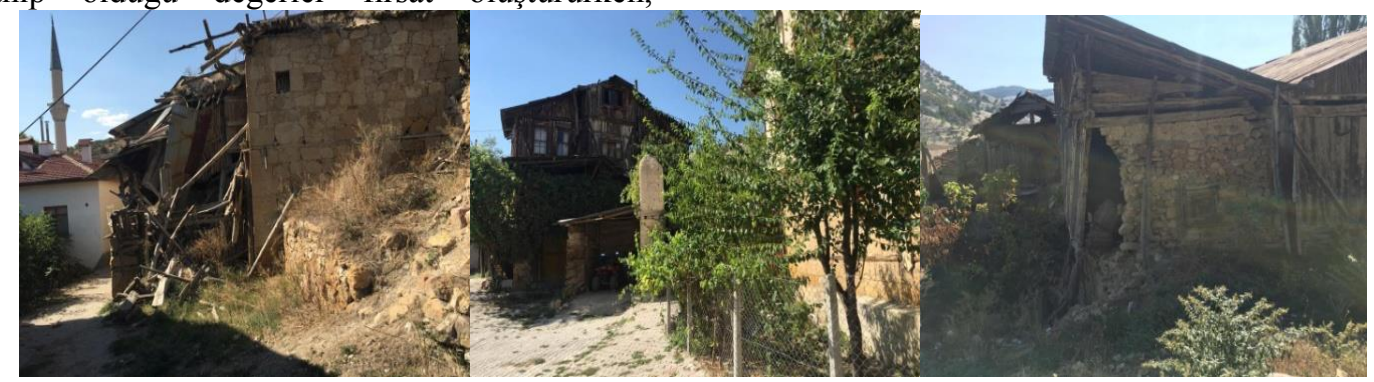

Şekil 19. Yapılardaki tahribat örnekleri 
Aynı zamanda yerleşme yakınında maden ocaklarının bulunması, tarımda verim düşüklüğüne ve kirliliğe sebep olmakta, Hırkatepe'nin cazibesini daha da azaltmaktadır.

\section{SONUC}

Sosyo-ekonomik ve ekolojik talepler karşısında kırsal alanların bu taleplere uyum sağlaması gerekli olmaktadır. Kentteki imkânların kıra kıyasla fazla oluşu göçe sebep olmakta ve küçük kırsal yerleşmeler giderek nüfus kaybetmekte ve kırsal mirasın yap1 taşları olan konutlarda yaşayan sayısı giderek azalmaktadır. Kırsal alanlarda sürdürülebilirliğin sağlanması kentlinin tarımsal ürün ve rekreasyon gibi ihtiyaçlarının karşılanması açısından da önem taşımaktadır. Dünyadaki kırsal mirası koruma çalışmalarına benzer şekilde, ülkemizdeki koruma çalışmaları da turizm çerçevesinde yürütülmektedir. Kentlerin yorucu ortamından uzaklaşmak için kırsal yerleşmeler son dönemde tatil amaciyla tercih edilen yerler haline gelmiştir. Dolayısıyla, bölgenin yerel özelliklerini göze ardı etmeyen, kentin ve kırsal alanın bütüncül yaklaşım içinde düşünüldüğü sürdürülebilir kırsal turizm çalışmaları önem kazanmaktadır. Bu bağlamda, yok olma tehdidi altında olan Hırkatepe'deki kırsal mirasın korunmasına yönelik tedbirlerin alınması gereklidir.

Koruma çalışmalarına başlamadan önce kültürel mirasın bulunduğu bölgenin aşağıdaki maddeler doğrultusunda iyi tanımlanması ve iyi analiz edilmesi gereklidir (CEMAT, 2003).

- Mekân organizasyonu (orman, sulak alanlar $\mathrm{vb}$ ile yapılı çevre)

- Referans noktaları (işaretler, su kanalları, dini yapılar vb.)

- İletişim kanalları (sokak dokusu, demir yolları vb.)

- Kırsal peyzaj (tarım alanı, havza, açık alan $\mathrm{vb)}$

- Geleneksel yapı özellikleri

- Kültür (toplumsal yapı) ve dil

- Yönetim

Kırsal miras, yapılı çevre, doğal ve kültürel özellikleri ile bir bütündür. Dolayısıyla, koruma, kırsal mirasın her bir parçasının detaylı analizini gerekli kılmaktadır. "Geleneksel kırsal mimari miras bulunduğu coğrafya ve yaşayan halkın tarihi, kültürü ve gelenekleri ile birlikte korunabildiğinde özgün değerini korur. Geleneksel yöntemlerle inşa edilmiş bir evin sadece çağdaş yöntemler ve teknolojiler kullanılarak restore edilmesi, tekil olarak yenilenmesi kırsal mirasın korunması için yeterli değildir" (Muşkara, 2017). Sosyal-kültürel, ekonomik, ekolojik, kurumsal ve mekânsal boyutları içeren geniş kapsamlı ve bütüncül bir bakış açısı ile kırsal mirası oluşturan özgün değerlerin sürdürülebilir korunmasına yönelik mekânsal ve işlevsel stratejilerin oluşturulması önemlidir (Özcan, 2017). Bu doğrultuda aşağıda belirtilen önerilerin uygulanması ekonomik, ekolojik ve sosyal faydalar sağlayacaktır.

- Yerel yönetimler tarafindan hibe, fon gibi desteklerle konutların tadilatı yapılarak kırsal mirasın sürdürülebilirliği sağlanmalı,

- Kirsal peyzajda, koruma-kullanma dengesi ve taşıma kapasitesi düşünülerek Hırkatepe'nin özgün dokusu korunmalı,

- Kırsal mirasın korunmasına yönelik halk ve yerel yönetimlerde bilinç oluşturulmalı,

- Ulaşım ve teknik alt yapı geliştirilmeli,

- Hırkatepe Höyüğü için peyzaj tasarım projesi oluşturulmalı,

- Gündüzalp Türbesi'nin bakımı yapılmalı,

- Yerleşme içinde ve çevresinde yer alan tarihi eserler koruma altına alınmalı,

- Yerel ürünlerin satışının da desteklendiği festivaller yapilmalı,

- Tarımsal üretim faaliyetleri desteklenerek yerel ürün satışı geliştirilmelidir.

Sonuç olarak, kırsal mirasın sürdürülebilirliğinin sağlanması yönünde yöreye özgü detaylı analizlerin yapıldığı çok aktörlü ve kapsamlı tasarım, planlama ve yönetim çalışmaları yapılmalıdır.

\section{KAYNAKLAR}

Ahunbay, Z., 2004. Tarihi çevre koruma ve restorasyon, İstanbul, YEM Yayınları, $212 \mathrm{~s}$.

Akgün, T., 2013. Kırsal mimari mirasın korunmas1 bağlamında Bayburt kırsal geleneksel evi. Karadeniz Teknik Üniversitesi Fen Bilimleri Enstitüsü Yüksek Lisans Tezi, Trabzon.

Anonim, 2019. Beypazarı Belediyesi, http://www.beypazari.bel.tr/tr/mahalleler/30 (Erişim Tarihi: 12 Mart 2019).

Avcı, Ü., Atik, M., 2016. Doğal peyzajın kırsal konut mimarisi üzerindeki etkileri: Beğiş susuzu örneği. Afyon Kocatepe Üniversitesi Sosyal Bilimler Dergisi, 18 (1): 153-171.

CEMAT, 2003. European rural heritage observation guide. $100 \mathrm{p}$.

Ceylan, S., 2012. Kirsal mimarinin örneklerinden "serenler"in coğrafi açıdan irdelenmesi. Doğu Coğrafya Dergisi, (27): 151-168.

Cohen, I. A., Sofer, M., 2017. Integrated rural heritage landscapes: the case of agricultural cooperative settlements and open space in Israel. Journal of Rural Studies, 54: 98-110.

ÇEKÜL, 2012. Anadolu'da kirsal mimarlık. 27 s.

Çevik, S., Eminağaoğlu, Z., Ersen, F., 2003. Natureeffective architecture settlements. Livable Environments \& Architecture, International Congress, Trabzon, s: 168-178. 
Çınar, H. 2014. Anadolu kırsal mimarisinin oluşum mantığ1: yer değiştiren Kesmez Köyü'nde mekân ve mekân düzeni. Selçuk Üniversitesi Fen Bilimleri Enstitüsü Yüksek Lisans Tezi, Konya.

Eminağaoğlu Z., Çevik, S., 2006. Doğa-Kırsal yerleşme birliktelikleri. Kafkas Üniversitesi, Artvin Orman Fakültesi Dergisi, 7 (1): 28-40.

Eres, Z., 2008. Dünyada geleneksel kırsal mimarinin kültür varlığ1 olarak tanımlanma süreci. Türkiye'de Geleneksel Kırsal Mimarinin Korunmas1: Tarihsel Süreç, Yasal Boyut, s: 457469.

Gündüzalp, M., 2003. Hırkatepe Köyü Gazi Gündüzalp Türbesi. https:// gazigunduzalp 879317061.wordpress.com/ (Erişim Tarihi: 15 Mart 2019).

İner, G., Erdoğan, N., 2010. Edirne/Uzunköprü/ Yeniköy kırsal konutlarının mimari ve yapısal karakteri. TÜBA Kültür Envanteri Dergisi, 8: $35-42$.

Kiper, T., 2013. Kentsel ve kırsal alanların planlanmasında kimliğin rolü. Türk Bilimsel Derlemeler Dergisi, 6 (2): 69-73.

Kurtuluş, B., Şahin, G.N., 2015. Tarsus Bölgesi'nde geleneksel kırsal mimari ve yaşam. TÜBA Kültür Envanteri Dergisi, 13: 101-124.

Levi, E.A., Taşçı, B., 2017. Ege'de kırsal mimari araştırmaları: Bayındır Köyleri. Megaron, 12 (3): 365-384.
Mioara, B., Teodora, M.I., 2015. The implication of international cooperation in the sustainable valorisation of rural touristic heritage. ProcediaSocial and Behavioral Sciences, 188: 222-229.

Muşkara, Ü., 2017. Kırsal ölçekte geleneksel konut mimarisinin korunması: Özgünlük. Sefad, 37: 437-448.

Özcan, K., 2017. Kırsal miras koruma stratejisi Sandıma Köyü, Bodrum. Millî Folklor, 29 (113): 40-53

Rapoport, A., 1969. House form and culture. Prentice Hall, Inc., Englewood Cliffs,N.J., London.

Şenol, P., Er Akan, A., 2011. Kırsal yaşam / kırsal konut: bir yaşam biçimi olarak geleneksel kırsal konut üretiminde Kızılcık Köyü Örneği. SDÜ Fen Edebiyat Fakültesi Dergisi, 24: 143-160.

TUİK, 2019. Türkiye İstatistik Kurumu, Ankara, https://biruni.tuik.gov.tr/medas/?kn=95\&locale =tr (Erişim Tarihi: 12 Mart 2019)

Uzunçarşıl1, İ.H., 1988. Osmanlı tarihi. Türk Tarih Kurumu, Ankara, s:128-130.

Yaman, Kocadağlı., A., 2013. Nüfus coğrafyası açısından bir inceleme: Beypazarı,. Sosyoloji Dergisi, 3 (27): 41-72.

Zhai, Z.J., Previtali, J.M., 2010. Ancient vernacular architecture: characteristics categorization and energy performance evaluation. Energy and Buildings, 42: 357-365. 